\title{
Modulation of antioxidant enzymes by salicylic acid in arsenic exposed Glycine max L.
}

\author{
V. Chandrakar ${ }^{1}$, A. Dubey ${ }^{2}$ and S. Keshavkant ${ }^{1 *}$ \\ ${ }^{1}$ School of Studies in Biotechnology, Pt. Ravishankar Shukla University, Raipur 492 010, India \\ ${ }^{2}$ Central Laboratory Facility, Chhattisgarh Council of Science and Technology, Raipur 492 010, India. \\ *Corresponding author: skeshavkant@gmail.com
}

\begin{abstract}
To investigate the physiological and metabolic attributes of arsenic (As) stress tolerance conferred by exogenous salicylic acid (SA), Glycine max L. (variety JS 335) seeds were aseptically germinated over filter paper moistened with SA $(500 \mu \mathrm{M})$ and/or10 and $100 \mu \mathrm{M}$ As (Sodium arsenite was used). On $2^{\text {nd }}$ and $5^{\text {th }}$ days of germination, the growing radicles were harvested, and analyzed for growth and different metabolic attributes. Findings exemplified that As significantly decreased germination percentage, radicle length, dry mass and activities of superoxide dismutase (SOD), catalase (CAT) and ascorbate peroxidase (APX), while stimulated the contents of As, reactive oxygen species (ROS), lipoxygenase (LOX), guaiacol peroxidase (POD) and proline. Additionally, isozymes of antioxidants were also scrutinized over Native-PAGE gels and were found to be altered considerably under As-stress. However, exogenous SA remarkably enhanced germination percentage, growth indices, activities of SOD, CAT and APX, and proline accumulation along with reduced As, ROS and LOX, and restoring POD in As-stressed seedlings. In conclusion, SA confers As-stress tolerance to Glycine max L. by regulating the antioxidant enzymes and proline accumulation thereby reduced As content and ROS production. Further study is intended, particularly at gene level, to understand precise mechanism(s) involved in SA-mediated Asstress tolerance.
\end{abstract}

Keywords: Antioxidant enzymes, arsenic toxicity, oxidative stress, reactive oxygen species, salicylic acid 


\section{Introduction}

Arsenic (As) is one of the non-essential metalloid present ubiquitously in nature. It is highly toxic to both animals and plants and has no known beneficial biological function (Armendariz et al., 2016). Both natural and anthropogenic activities, such as, mining, semi-conductor manufacturing, irrigation by As contaminated water, use of fossil fuels and As based pesticides/ fertilizers in agriculture, and waste disposal lead to severe contamination by it in the surrounding environment (Chandrakar et al., 2016). Arsenic exists in both organic and inorganic forms, out of which the later is predominantly present in the environment, particularly as arsenite $\left(\mathrm{As}^{\mathrm{III}}\right)$ and arsenate $\left(\mathrm{As}^{\mathrm{V}}\right)$ (Armendariz et al., 2016). Arsenate is a chemical analogue of phosphate and is taken up by plant roots through high affinity phosphate uptake systems, whereas, $\mathrm{As}^{\mathrm{III}}$ is taken up via aquaglyceroporins (Chandrakar et al., 2016). Between the two, $\mathrm{As}^{\mathrm{III}}$ is 100 -fold more toxic than $\mathrm{As}^{\mathrm{v}}$, due to its lovingness towards - $\mathrm{SH}$ groups of both enzymes and proteins leading to inhibition of cellular functions, which ultimately results in cell death. Plants, on exposure to phytotoxic amounts of As, induce overproduction of reactive oxygen species (ROS), such as, superoxide anion $\left(\mathrm{O}_{2}{ }^{--}\right)$, hydroxyl radical $\left(\mathrm{OH}^{\circ}\right)$ and hydrogen peroxide $\left(\mathrm{H}_{2} \mathrm{O}_{2}\right)$, resulting in oxidative stress imposing array of irreparable injuries (Kaur et al., 2012). These ROS are largely shown to react with all sorts of cellular macromolecules like lipids, carbohydrates, proteins and nucleic acids (Parkhey et al., 2014a). Moreover, oxidation of lipid moiety can also be initiated enzymatically by lipoxygenase (LOX) and is believed to be an important factor of growth inhibition in plants exposed to heavy metals (Mostofa and Fujita, 2013). In order to combat against the excessive ROS and to protect the cells under oxidative environments, plant cells possess a complex network of defense system, which comprises both enzymatic and non-enzymatic components (Chandra and Keshavkant, 2016; Chandrakar et al., 2016). The enzymatic component includes superoxide dismutase (SOD), catalase (CAT), guaiacol peroxidase (POD) and ascorbate peroxidase (APX) (Dong et al., 2014). This function may also be achieved by a concerted action of low molecular weight non-enzymatic antioxidants, such as, $\alpha$-tocopherol, proline, ascorbate, glutathione and phenolic compounds (Raza et al., 2014; Singh et al., 2015b). The very first step taken towards detoxification of cellular ROS is by SOD (Keshavkant and Naithani, 2001). SOD is one of the metalloenzymes that leads conversion of two $\mathrm{O}_{2}{ }^{--}$ radicals into $\mathrm{H}_{2} \mathrm{O}_{2}$ and $\mathrm{O}_{2}$ (Keshavkant and Naithani, 2001). CAT and POD catalyzes the breakdown of $\mathrm{H}_{2} \mathrm{O}_{2}$ (Chandra and Keshavkant, 2016). Although, CAT is apparently absent in the chloroplasts, $\mathrm{H}_{2} \mathrm{O}_{2}$ may be detoxified in a reaction catalyzed by an ascorbate-specific peroxidase that is normally found in abundance in this organelle through the ascorbateglutathione cycle (Chandrakar et al., 2016).

Salicylic acid (SA) has been considerably recognized as an endogenous natural signal molecule involved in plant's defense mechanisms by regulating both physiological and biochemical processes (Odjegba, 2012; Dong et al., 2015). Further, it is also well documented that SA enhances accumulation of proline thereby minimizes toxic effects of metals/metalloids (Mostofa and Fujita, 2013). All these researches demonstrated that SA-regulated abiotic stress tolerance in plants are involved in antioxidant responses, thus suggesting that protection of plants from oxidative damage by SA is intimately linked with an enhanced antioxidant system (Parkhey et al., 2014b). A recent report demonstrated that co-application of SA with As, was more effective in reducing metalloid exerted oxidative injury than its pre-treatment (Singh et al., 2015a). 
The present research was aimed to 1) analyze the physiological effects of As in Glycine max L. seeds/ seedlings, 2) investigate the levels of As content, $\mathrm{O}_{2}{ }^{--}$, $\mathrm{OH}^{\cdot}$ and $\mathrm{H}_{2} \mathrm{O}_{2}, 3$ ) determine changes in the activities of various enzymes (SOD, CAT, POD, APX and LOX), 4) isozyme profiling of antioxidant enzymes, 5) monitor change in proline content, and 6) modulation of Asinduced stress responses by exogenous addition of SA.

\section{Materials and Methods}

\subsection{Plant material, treatments and growth analysis}

Glycine max L. (variety JS 335) seeds were washed initially with $1 \%(\mathrm{v} / \mathrm{v})$ sodium hypochlorite solution for 5 min following washing (5 times) with MilliQ water (MW) (Millipore, Gradient A-10, USA). Primarily, disinfected seeds were germinated over two layers of filter paper towels, pre-soaked with a series of As(Sodium arsenite, used as a source of As) solution si.e., 10, 25, 50, 75, 100 and $125 \mu \mathrm{M}$, in germination boxes of $26 \times 16 \times 3 \mathrm{~cm}$ size (Parkhey et al., 2014a). These boxes were kept in darkness at room temperature $\left(26-28^{\circ} \mathrm{C}\right)$. Respective growth medium $(10 \mathrm{~mL})$ was supplied to the germinating seeds in each $30 \mathrm{~h}$. Looking to the germination count, two concentrations i.e. 10 and $100 \mu \mathrm{M} \mathrm{As}$, were then selected for current study, where seeds revealed $00 \%$ (but the rate of germination was slow compared to MW-grown control seeds) and $74 \%$ reductions in germination percentage, respectively on $5^{\text {th }}$ day of investigation. Further, a dose of SA fixed was $500 \mu \mathrm{M}$, based on screening experiments. In a preliminary investigation, adding various concentrations of SA (100, 200, 300 and $400 \mu \mathrm{M})$ partially rescued the adverse impacts of As on growth in Glycine max L., but $500 \mu \mathrm{M}$ SA was found to confer maximum tolerance (as evidenced by $45 \%$ rise in biomass) towards As $(100 \mu \mathrm{M})$ toxicity. Hence, $500 \mu \mathrm{M}$ SA was used in this entire experiment.
A randomized block design comprising of a control (C, without As and SA) and five treatments; 500 $\mu \mathrm{M}$ SA (T1), $10 \mu \mathrm{M}$ As (T2), $10 \mu \mathrm{M}$ As $+500 \mu \mathrm{M}$ SA (T3), $100 \mu \mathrm{M}$ As (T4), and $100 \mu \mathrm{M}$ As +500 $\mu$ M SA (T5) were used. Sixty sterilized seeds were then placed for germination in each of the treatments, following the procedure of Parkhey et al. (2014a), as mentioned previously. On $2^{\text {nd }}$ and $5^{\text {th }}$ days of sample incubation, germination percentage was assessed and then their radicles were removed carefully. The lengths of the ten randomly selected radicles were measured with the help of a scale $(\mathrm{mm})$, to record smallest change in their lengths. Likewise, ten radicles were pooled in each replicate and weighed in an electronic balance (Sartorius, Sweden). Dry mass (DM) of these radicles was measured after placing them in a hot air oven at $60{ }^{\circ} \mathrm{C}$ for $72 \mathrm{~h}$. Each experiment was performed in five replicates. Left over radicles were stored in sterile vials at $-80{ }^{\circ} \mathrm{C}$ (U410, Eppendorf, Germany) for further analyses.

All the chemicals used in this study are of standard purity and analytical grades, supplied by Qualigens and Merck, India, or Sigma, USA.

\subsection{Arsenic content}

To determine As content, weighed amounts (0.1 g) of dried radicles were digested using $\mathrm{HNO}_{3}$ : $\mathrm{H}_{2} \mathrm{O}_{2}: \mathrm{H}_{2} \mathrm{O}$ in the ratio of $5: 1: 1$ (v:v:v) at $80{ }^{\circ} \mathrm{C}$ until a transparent solution was obtained (LozanoRodriguez et al., 1995). The volume of digested sample was made up to $15 \mathrm{~mL}$ with $\mathrm{MW}$, and amount of As in it was monitored using atomic absorption spectrometer coupled to a hydride generation system (Agilent, AA240, USA). The standard reference materials of metals (Merck, Darmstadt, Germany) were used for calibration and quality assurance for analysis. 


\subsection{Reactive oxygen species}

$\mathrm{O}_{2}{ }^{--}$content was measured following the method of Schopfer et al. (2001). Excised radicles (0.2 g) were imbibed in $20 \mathrm{mM}$ phosphate buffer, $\mathrm{pH} 6$, consisting 2, 3-Bis (2-methoxy-4-nitro-5-sulfophenyl)-2H-tetrazolium-5-carboxanilide $(500 \mu \mathrm{M})$ in dark at $26^{\circ} \mathrm{C}$, on a shaker at $50 \mathrm{rpm}$. Absorbance of the soaking medium was read at $470 \mathrm{~nm}$ in UV-Vis spectrophotometer (Lambda 25, Perkin Elmer, USA). $\mathrm{O}_{2}{ }^{--}$content was calculated using an extinction coefficient $2.16 \times 10^{4} \mathrm{M}^{-1}$

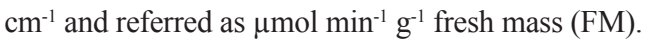
To measure $\mathrm{OH}^{*}$, radicles $(0.2 \mathrm{~g})$ were homogenized in $2 \mathrm{~mL}$ of phosphate buffer (10 mM, pH 7.4) containing $15 \mathrm{mM}$ 2-deoxyribose and incubated at $37{ }^{\circ} \mathrm{C}$ for $2 \mathrm{~h}$. An aliquot of above solution was mixed with $3 \mathrm{~mL}$ thiobarbituric acid $(0.5 \%(\mathrm{w} / \mathrm{v})$ in $5 \mathrm{mM} \mathrm{NaOH})$ and $1 \mathrm{~mL}$ glacial acetic acid (Kaur et al., 2012). Now, this solution was heated at $100{ }^{\circ} \mathrm{C}$ for $30 \mathrm{~min}$ and then cooled at 4 ${ }^{\circ} \mathrm{C}$ for $10 \mathrm{~min}$. Absorbance was recorded at $532 \mathrm{~nm}$ and corrected for non-specific absorbance at $600 \mathrm{~nm}$. Content of $\mathrm{OH}^{*}$ was calculated using an extinction coefficient of $0.155 \mathrm{M}^{-1} \mathrm{~cm}^{-1}$ and expressed as nmol g-1 FM.

To assess $\mathrm{H}_{2} \mathrm{O}_{2}$ content, weighed amounts $(0.2 \mathrm{~g})$ of radicles were extracted with $2 \mathrm{~mL}$ of $0.1 \%(\mathrm{w} / \mathrm{v})$ trichloroacetic acid (TCA) and centrifuged at 12,000 rpm for $15 \mathrm{~min}$ at $25^{\circ} \mathrm{C}$ (Velikova et al., 2000). An aliquot of supernatant was added to equal volumes of $10 \mathrm{mM}$ phosphate buffer ( $\mathrm{pH} 7$ ) and potassium iodide (1 M). Now, absorbance was read at $390 \mathrm{~nm}$. $\mathrm{H}_{2} \mathrm{O}_{2}$ content was calculated using an extinction coefficient $0.28 \mu \mathrm{M}^{-1} \mathrm{~cm}^{-1}$ and was expressed as $\mu \mathrm{mol} \mathrm{g}^{-1} \mathrm{FM}$.

\subsection{Determination of LOX activity}

LOX (EC 1.13.11.12) was assayed according to the method of Olaiya (2010). For this, the substrate was prepared by adding $10 \mu \mathrm{L}$ linoleic acid to $25 \mathrm{~mL}$ sodium tetraborate $(0.1 \mathrm{M})$ containing $0.1 \%(\mathrm{v} / \mathrm{v})$
Tween-20. Activity was determined by adding 100 $\mu \mathrm{L}$ each of enzyme extract and substrate to $2.9 \mathrm{~mL}$ phosphate buffer $(0.1 \mathrm{M}, \mathrm{pH} 4.5)$. The absorbance was recorded at $234 \mathrm{~nm}$. LOX activity was calculated using the extinction coefficient $0.025 \mathrm{M}^{-1} \mathrm{~cm}^{-1}$ and expressed as $\mu \mathrm{mol} \mathrm{min}^{-1} \mathrm{mg}^{-1}$ protein.

\subsection{Assay of antioxidant enzymes}

Samples $(0.2 \mathrm{~g})$ were extracted with $2 \mathrm{~mL}$ of $10 \mathrm{mM}$ phosphate buffer ( $\mathrm{pH} 7.2$ ), containing $1 \mathrm{mM}$ EDTA, $2 \mathrm{mM}$ DTT and $0.2 \%(\mathrm{v} / \mathrm{v})$ Triton X-100 and centrifuged at $14,000 \mathrm{rpm}$ for $20 \mathrm{~min}$ at $4{ }^{\circ} \mathrm{C}$. Supernatant thus obtained was used for estimations of protein and antioxidants.

Protein content was assessed following the procedure of Bradford (1976). Bovine serum albumin was used to prepare standard curve.

Following the method of Marklund and Marklund (1974), activity of SOD (EC 1.15.1.1) was determined by estimating the percent inhibition of pyrogallol auto-oxidation by the enzyme at $420 \mathrm{~nm}$. For this, $2.74 \mathrm{~mL}$ of Tris- $\mathrm{HCl}$ buffer (50 mM, $\mathrm{pH} 8.2$ ) containing $1 \mathrm{mM}$ each of DETAPAC and EDTA was taken in a test tube, to which $0.2 \mathrm{~mL}$ of enzyme extract was added. The reaction was initiated by adding $60 \mu \mathrm{L}$ of pyrogallol $(0.2 \mathrm{mM}$ of pyrogallol dissolved in $10 \mathrm{mM} \mathrm{HCl}$ ) and the change in absorbance was recorded at $420 \mathrm{~nm}$ after 6 min of incubation at room temperature. The activity of enzyme was expressed as Units of SOD $\mathrm{min}^{-1} \mathrm{mg}^{-1}$ protein.

Activity of CAT (EC 1.11.1.6) was assayed following the method of Chance and Maehly (1955). For its estimation, the decomposition of $\mathrm{H}_{2} \mathrm{O}_{2}$ was measured by recording the fall in absorbance at $240 \mathrm{~nm}$. Assay mixture comprised of $2.74 \mathrm{~mL}$ of potassium phosphate buffer (37.5 mM, pH 6.8) and $60 \mu \mathrm{L}$ of extract. Enzyme activity was triggered by adding $200 \mu \mathrm{L}$ of $\mathrm{H}_{2} \mathrm{O}_{2}(60 \mathrm{mM})$. The change in absorbance was record- 
ed for $5 \mathrm{~min}$ at an interval of $15 \mathrm{sec}$. Activity of CAT was calculated using an extinction coefficient of $0.039 \mathrm{M}^{-1}$ $\mathrm{cm}^{-1}$ and expressed as nmol min ${ }^{-1} \mathrm{mg}^{-1}$ protein.

POD (EC 1.11.1.7) activity was measured following the method of Chance and Maehly (1955). In a test tube, $2.3 \mathrm{~mL}$ of phosphate buffer (0.02 M, pH 6.4), $0.5 \mathrm{~mL}$ guaiacol $(12 \mathrm{mM})$ and $0.2 \mathrm{~mL}$ enzyme extract were taken. Reaction was triggered by adding $20 \mu \mathrm{L}$ of $3 \%(\mathrm{v} / \mathrm{v}) \mathrm{H}_{2} \mathrm{O}_{2}$. The change in absorbance was read at $470 \mathrm{~nm}$ after $3 \mathrm{~min}$ of incubation at room temperature, and activity was expressed in terms of $\mathrm{mmol}$ $\mathrm{min}^{-1} \mathrm{mg}^{-1}$ protein.

Activity of APX (EC 1.11.1.11) was assayed according to Nakano and Asada (1981) by monitoring the rate of ascorbate oxidation at $290 \mathrm{~nm}$. The reaction mixture comprised of $2.3 \mathrm{~mL}$ of potassium phosphate buffer (0.025 M, pH 7.0), $500 \mu \mathrm{L}$ of ascorbic acid (0.0025 $\mathrm{M}), 190 \mu \mathrm{L}$ of $\operatorname{EDTA}(0.001 \mathrm{M})$ and $10 \mu \mathrm{L}$ of isolated enzyme. Immediately after the addition of $10 \mu \mathrm{L}$ of $\mathrm{H}_{2} \mathrm{O}_{2}(0.1 \mathrm{M})$ into assay mixture, initial absorbance was measured at $290 \mathrm{~nm}$. After $20 \mathrm{~min}$ of incubation at room temperature, absorbance of the mixture was once again recorded. Enzyme activity was calculated following the extinction coefficient of $0.0028 \mathrm{M}^{-1} \mathrm{~cm}^{-1}$ and expressed as mmol $\mathrm{min}^{-1} \mathrm{mg}^{-1}$ protein.

\subsection{Isozyme analysis}

Electrophoretic separation of SOD, CAT, POD and APX were performed on native polyacrylamide gels (10\%) using Tris-glycine buffer ( $5 \mathrm{mM}, \mathrm{pH} 8.3$ ) (in case of APX, running buffer consists of $4 \mathrm{mM}$ ascorbate), at $4{ }^{\circ} \mathrm{C}$ for 2 $\mathrm{h}$ with a constant current of $20 \mathrm{~mA}$, using Mini-Protean tetra cell (BioRad, USA). After complete run, gels were imaged and analyzed using a Gel-Doc system (BioRad, USA). To visualize the SOD, gels were incubated in the dark for $20 \mathrm{~min}$ in the $2.45 \mathrm{mM}$ nitro blue tetrazolium (NBT) solution, and were then immersed in $36 \mathrm{mM}$ dipotassium hydrogen phosphate ( $\mathrm{pH} 7.8$ ) containing $28 \mu \mathrm{M}$ ribofla- vin and $28 \mathrm{mM}$ TEMED, until the gel turns blue except the region showing SOD activity (Chun-xi et al., 2007). Isozymes of CAT were stained following the method described by Woodbury et al. (1971). The gels were incubated in $0.03 \%(\mathrm{v} / \mathrm{v}) \mathrm{H}_{2} \mathrm{O}_{2}$ solution for $10 \mathrm{~min}$. The gels were rinsed quickly in MW and stained in a solution containing $1 \%(\mathrm{w} / \mathrm{v})$ each of potassium ferricyanide and ferric chloride. As soon as a green colour began to appear, gels were washed with MW. Isozymes of POD were revealed following Srivastava and Huystee (1977). The gels were equilibrated with $100 \mathrm{mM}$ potassium phosphate buffer $(\mathrm{pH} 6.5)$ for $15 \mathrm{~min}$ and then in 12.5 $\mathrm{mM}$ guaiacol solution containing benzidine $(1.7 \mathrm{mM})$ and $\mathrm{H}_{2} \mathrm{O}_{2}(12 \mathrm{mM})$. After gentle shaking, brown coloured bands appeared against a clear background. For APX detection, gels were equilibrated with $50 \mathrm{mM}$ sodium phosphate buffer ( $\mathrm{pH} 7$ ) and $2 \mathrm{mM}$ ascorbate for $30 \mathrm{~min}$ (Mittler and Zilinskas, 1993). Afterwards, the gels were incubated with $50 \mathrm{mM}$ sodium phosphate buffer ( $\mathrm{pH}$ 7) containing $4 \mathrm{mM}$ ascorbate and $4 \mathrm{mM} \mathrm{H}_{2} \mathrm{O}_{2}$ for $20 \mathrm{~min}$. Finally, gels were washed twice with sodium phosphate buffer $(50 \mathrm{mM}, \mathrm{pH} 7)$ and stained in $50 \mathrm{mM}$ sodium phosphate buffer ( $\mathrm{pH}$ 7.8) containing $28 \mathrm{mM}$ TEMED and $2.45 \mathrm{mMNBT}$. The reaction was continued for 10-15 min and stopped by a brief wash with MW.

\subsection{Proline determination}

Proline was estimated according to Bates et al. (1973). $0.5 \mathrm{~g}$ radicle was homogenized with $10 \mathrm{~mL}$ of $3 \%$ $(\mathrm{w} / \mathrm{v})$ sulfo-salicylic acid and centrifuged at 6,000 rpm for $15 \mathrm{~min}$ at $26^{\circ} \mathrm{C}$. Supernatant $(2 \mathrm{~mL})$ was mixed with $2 \mathrm{~mL}$ each of ninhydrin reagent and glacial acetic acid. The mixture was incubated at $100{ }^{\circ} \mathrm{C}$ for $60 \mathrm{~min}$, and cooled at room temperature. Then, $4 \mathrm{~mL}$ toluene was added and the chromophore containing toluene was aspirated out and its absorbance was recorded at $520 \mathrm{~nm}$ taking toluene as a blank. Its amount was expressed as $\mathrm{mg} \mathrm{g}^{-1} \mathrm{FM}$. 


\subsection{Statistical analysis}

All the investigations were performed twice with five separate replications. The data obtained were subjected to one-way ANOVA, and the mean differences were compared by Duncun's multiple range tests using SPSS software (Ver. 16.0).

\section{Results}

\subsection{Growth analysis}

Growth indices of Glycine max L. radicles were negatively influenced by As treatment. The $10 \mu \mathrm{M}$ (T2) As slightly reduced the germination rate (8\%), length (40\%), and DM (25\%) of the radicles, as compared to the MW-treated control, on $2^{\text {nd }}$ day of investigation (Table 1). These reductions were found to be substantially high (germination: $74 \%$, radicle length: $88 \%$ and DM: 83\%) under T4 (100 $\mu \mathrm{M}$ As) treatment, on $5^{\text {th }}$ day of analysis, compared to the control (Table 1).
On the other hand, SA (T1), as seed soaking in absence of As, stimulated the growth traits $(\mathrm{P}<0.05)$ higher than the controls. SA, also uplifted the growth of the seedlings grown in T3 $(10 \mu \mathrm{M}$ As $+500 \mu \mathrm{M} \mathrm{SA})$ and T5 $(100 \mu \mathrm{M}$ As $+500 \mu \mathrm{M} \mathrm{SA})$ and the data obtained were statistically significant $(\mathrm{P}<0.05)$ than those of the seeds grown under As alone (T2 and T4) (Table 1).

\subsection{Arsenic content}

Considerable $(\mathrm{P}<0.05)$ rise in As accumulation was measured in respect to both concentration and length of exposure (Table 1). Amounts of As measured in the radicles of $\mathrm{T} 2(10 \mu \mathrm{M} \mathrm{As})$ and $\mathrm{T} 4(100 \mu \mathrm{M} \mathrm{As})$ were $20.41 \mu \mathrm{g} \mathrm{As} \mathrm{g}^{-1} \mathrm{DM}$ and $23.54 \mu \mathrm{g} \mathrm{As} \mathrm{g}^{-1} \mathrm{DM}$ respectively, on $2^{\text {nd }}$ day, while with increased expo-

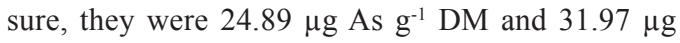

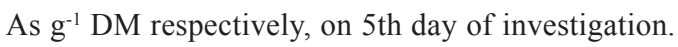
However, an exogenous addition of SA caused limited (7-27\%) accumulation of As in T2 and T4 treated Glycine max L. (Table 1).

Table 1. Effects of arsenic and/ or salicylic acid treatments on germination percentage, radicle length, dry mass, arsenic and proline content of Glycine $\max \mathrm{L}$. on $2^{\text {nd }}$ and $5^{\text {th }}$ days of exposure.

\begin{tabular}{|c|c|c|c|c|c|c|c|c|c|c|}
\hline \multirow[t]{2}{*}{$\begin{array}{l}\text { Treat } \\
\text { ments }\end{array}$} & \multicolumn{2}{|c|}{ Germination (\%) } & \multicolumn{2}{|c|}{$\begin{array}{c}\text { Radicle length } \\
(\mathrm{mm})\end{array}$} & \multicolumn{2}{|c|}{ Dry mass (g) } & \multicolumn{2}{|c|}{ As content $\left(\mu g^{-1}\right.$ DM) } & \multicolumn{2}{|c|}{ Proline $\left(\mathrm{mg} \mathrm{g}^{-1} \mathbf{F M}\right)$} \\
\hline & $2^{\text {nd }}$ Day & $5^{\text {th }}$ Day & $2^{\text {nd }}$ Day & $5^{\text {th }}$ Day & $2^{\text {nd }}$ Day & $5^{\text {th }}$ Day & $2^{\text {nd }}$ Day & $5^{\text {th }}$ Day & $2^{\text {nd }}$ Day & $5^{\text {th }}$ Day \\
\hline $\mathrm{C}$ & $90^{\mathrm{b}} \pm 0.57$ & $100^{\mathrm{a}} \pm 0$ & $15^{b} \pm 1$ & $75^{c} \pm 2$ & $0.04^{b} \pm 0.005$ & $0.12^{b} \pm 0.005$ & - & - & $0.2^{f} \pm 0.01$ & $0.31^{\mathrm{e}} \pm 0.006$ \\
\hline $\mathrm{T} 1$ & $100^{\mathrm{a}} \pm 0$ & $100^{\mathrm{a}} \pm 0$ & $18^{\mathrm{a}} \pm 2$ & $86^{a} \pm 1$ & $0.06^{\mathrm{a}} \pm 0.005$ & $0.13^{\mathrm{a}} \pm 0.01$ & - & - & $0.23^{e} \pm 0.002$ & $0.36^{\mathrm{e}} \pm 0.02$ \\
\hline $\mathrm{T} 2$ & $83^{c} \pm 1$ & $100^{\mathrm{a}} \pm 0$ & $9^{c} \pm 1$ & $41^{\mathrm{d}} \pm 1$ & $0.03^{c} \pm 0.005$ & $0.08^{c} \pm 0.005$ & $20.41^{b} \pm 0.05$ & $24.89^{b} \pm 0.05$ & $0.31^{\mathrm{d}} \pm 0.04$ & $0.47^{\mathrm{d}} \pm 0.05$ \\
\hline $\mathrm{T} 3$ & $90^{b} \pm 2$ & $100^{\mathrm{a}} \pm 0$ & $16^{\mathrm{ab}} \pm 1$ & $80^{b} \pm 2$ & $0.04^{b} \pm 0.005$ & $0.12^{b} \pm 0.01$ & $14.79^{c} \pm 0.05$ & $18.43^{c} \pm 0.01$ & $0.53^{c} \pm 0.07$ & $0.93^{b c} \pm 0.005$ \\
\hline $\mathrm{T} 4$ & $13^{e} \pm 3$ & $26^{c} \pm 3$ & $2^{\mathrm{e}} \pm 1$ & $9^{f} \pm 3$ & $0.006^{e} \pm 0.005$ & $0.02^{\mathrm{d}} \pm 0.01$ & $23.54^{\mathrm{a}} \pm 0.03$ & $31.97^{\mathrm{a}} \pm 0.06$ & $1.12^{b} \pm 0.01$ & $2.05^{b} \pm 0.19$ \\
\hline T5 & $35^{\mathrm{d}} \pm 5$ & $70^{b} \pm 2$ & $8^{d} \pm 1$ & $34^{\mathrm{e}} \pm 4$ & $0.01^{\mathrm{d}} \pm 0.005$ & $0.03^{\mathrm{d}} \pm 0.005$ & $21.77^{b} \pm 0.05$ & $25.93^{b} \pm 0.05$ & $1.49^{\mathrm{a}} \pm 0.03$ & $2.66^{\mathrm{a}} \pm 0.03$ \\
\hline
\end{tabular}

In this table, $\mathrm{C}=$ control, $\mathrm{T} 1=500 \mu \mathrm{M} \mathrm{SA}, \mathrm{T} 2=10 \mu \mathrm{M}$ As, $\mathrm{T} 3=10 \mu \mathrm{M}$ As $+500 \mu \mathrm{M} \mathrm{SA}, \mathrm{T} 4=100 \mu \mathrm{M}$ As and T5 $=100 \mu \mathrm{M}$ As $+500 \mu \mathrm{M}$ SA. Data are mean \pm SD of five individual replicates. Means followed by small letters are significantly different at $\mathrm{P}<0.05$ 
Table 2. Amounts of superoxide anions, hydroxyl radicals, hydrogen peroxide and lipoxygenase in Glycine max L. radicles, harvested after $2^{\text {nd }}$ and $5^{\text {th }}$ days of growth under experimental solutions.

\begin{tabular}{|c|c|c|c|c|c|c|c|c|}
\hline \multirow[t]{2}{*}{ Treatments } & \multicolumn{2}{|c|}{ 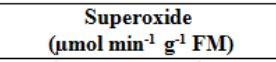 } & \multicolumn{2}{|c|}{$\begin{array}{c}\text { Hydroxyl radical } \\
\text { (nmol g } \mathbf{~ g M}^{-1} \text { FM) }\end{array}$} & \multicolumn{2}{|c|}{$\begin{array}{l}\text { Hydrogen peroxide } \\
\left(\mu \mathrm{mol} \mathrm{g^{-1 }} \mathrm{FM}\right)\end{array}$} & \multicolumn{2}{|c|}{ 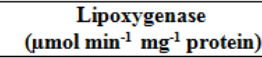 } \\
\hline & $2^{\text {nd }}$ Day & $5^{\text {th }}$ Day & $2^{\text {nd }}$ Day & $5^{\text {th }}$ Day & $2^{\text {nd }}$ Day & $5^{\text {th }}$ Day & $2^{\text {nd }}$ Day & $5^{\text {th }}$ Day \\
\hline $\mathrm{C}$ & $0.84^{e} \pm 0.18$ & $1.68^{a} \pm 0.79$ & $5.47^{\circ} \pm 1.39$ & $8.46^{d} \pm 0.07$ & $0.23^{d} \pm 0.009$ & $0.36^{d} \pm 0.007$ & $0.46^{e} \pm 0.03$ & $0.61^{e} \pm 0.16$ \\
\hline $\mathrm{T} 1$ & $0.51^{e} \pm 0.13$ & $1.39^{\mathrm{a}} \pm 0.16$ & $3.33^{f} \pm 0.36$ & $6.03^{e} \pm 0.09$ & $0.07^{e} \pm 0.004$ & $0.2^{e} \pm 0.009$ & $0.27^{\mathrm{e}} \pm 0.11$ & $0.40^{\mathrm{e}} \pm 0.08$ \\
\hline $\mathrm{T} 2$ & $2.52^{c} \pm 0.31$ & $8.87^{c} \pm 1.27$ & $8.96^{c} \pm 0.42$ & $10.86^{c} \pm 0.18$ & $0.42^{c} \pm 0.008$ & $0.54^{c} \pm 0.004$ & $1.56^{c} \pm 0.09$ & $1.83^{c} \pm 0.16$ \\
\hline $\mathrm{T} 3$ & $1.96^{\mathrm{d}} \pm 0.54$ & $6.73^{d} \pm 0.25$ & $6.4^{\mathrm{d}} \pm 0.08$ & $8.71^{d} \pm 0.21$ & $0.26^{d} \pm 0.007$ & $0.38^{d} \pm 0.005$ & $0.77^{d} \pm 0.03$ & $1.18^{d} \pm 0.03$ \\
\hline $\mathrm{T} 4$ & $20.62^{\mathrm{a}} \pm 1.42$ & $24.2^{\mathrm{a}} \pm 0.48$ & $23.96^{a} \pm 0.36$ & $28.71^{a} \pm 0.05$ & $0.79^{\mathrm{a}} \pm 0.007$ & $1.24^{\mathrm{a}} \pm 0.008$ & $4.46^{a} \pm 0.15$ & $5.15^{a} \pm 0.65$ \\
\hline $\mathrm{T} 5$ & $17.42^{b} \pm 1.25$ & $21.84^{b} \pm 0.8$ & $17.24^{b} \pm 0.18$ & $21.5^{b} \pm 0.48$ & $0.63^{b} \pm 0.006$ & $1.08^{b} \pm 0.008$ & $3.39^{b} \pm 0.45$ & $4.16^{b} \pm 0.22$ \\
\hline
\end{tabular}

In this table, $\mathrm{C}=$ control, $\mathrm{T} 1=500 \mu \mathrm{M} \mathrm{SA}, \mathrm{T} 2=10 \mu \mathrm{M}$ As, $\mathrm{T} 3=10 \mu \mathrm{M} \mathrm{As}+500 \mu \mathrm{M} \mathrm{SA}, \mathrm{T} 4=100 \mu \mathrm{M}$ As and T5 $=100 \mu \mathrm{M}$ As $+500 \mu \mathrm{M}$ SA. Data presented are mean \pm SD of five separate observations. Different letters indicate significant difference between treatments at $\mathrm{P}<0.05$

\subsection{Reactive oxygen species}

Increases in As concentration from $10 \mu \mathrm{M}$ (T2) to $100 \mu \mathrm{M}$ (T4), significantly $(\mathrm{P}<0.05)$ enhanced the levels of all the three $\operatorname{ROS}\left(\mathrm{O}_{2}{ }^{\cdot-}: 801-2880 \%\right.$, $\mathrm{OH}^{*}: 198-524 \%, \mathrm{H}_{2} \mathrm{O}_{2}: 234-539 \%$ ), compared to the non-treated controls, on $5^{\text {th }}$ day of analysis (Table 2). Data also indicated that As-induced damage in Glycine $\max \mathrm{L}$. is mitigated by exogenous SA up to a large extent $(\mathrm{P}<0.05)$ by controlling As uptake (7-27\%), thereby reducing the ROS accumulation (Table 2). Least levels of $\mathrm{O}_{2}{ }^{--}\left(0.51 \mu \mathrm{mol} \mathrm{min}{ }^{-1} \mathrm{~g}^{-1}\right.$ FM), $\mathrm{OH}^{-}\left(3.33 \mathrm{nmol} \mathrm{g}{ }^{-1} \mathrm{FM}\right)$ and $\mathrm{H}_{2} \mathrm{O}_{2}(0.07 \mu \mathrm{mol}$ $\left.\mathrm{g}^{-1} \mathrm{FM}\right)$ were recorded in SA (T1) grown seedlings (Table 2).

\subsection{Lipoxygenase}

Alike ROS, T2 (10 $\mu \mathrm{M} \mathrm{As)} \mathrm{and} \mathrm{T4} \mathrm{(100} \mu \mathrm{M} \mathrm{As})$ significantly $(503-1193 \%, \mathrm{P}<0.05)$ stimulated the LOX also, on $2^{\text {nd }}$ day of investigation, and was found to be increased further with extended exposure $(\mathrm{r}=$ 0.97, $\mathrm{P}<0.05)$ and As accumulation $(\mathrm{r}=0.81, \mathrm{P}<$ 0.05 ) (Table 2). However, supplementation of SA along with As (T3 and T5) declined (almost up to $50 \%$ ) the LOX activity in Glycine max L. (Table 2).

\subsection{Antioxidants}

Activities of SOD, CAT, POD and APX in response to As (T2: $10 \mu \mathrm{M} \mathrm{As}$, and $\mathrm{T} 4: 100 \mu \mathrm{M} \mathrm{As}$ ) and its combination with SA (T3:10 $\mu \mathrm{M}$ As $+500 \mu \mathrm{M}$ SA and T5: $100 \mu \mathrm{M} \mathrm{As}+500 \mu \mathrm{M} \mathrm{SA}$ ) are observed to perform differently (Figures 1, 3, 5 and 7). Activities of SOD, CAT and APX were decreased (73\%, $75 \%$ and $28 \%$, respectively) significantly $(\mathrm{P}<0.05)$, while POD increased (40\%) with advancing (24.89 $\mu \mathrm{g} \mathrm{As} \mathrm{g}^{-1} \mathrm{DM}$ to $31.97 \mu \mathrm{g}$ As g $\left.{ }^{-1} \mathrm{DM}\right)$ As accumulation. However, addition of SA either stimulated their activities over the values of the non-treated control or restored over those values recorded in As alone (T2 and T4) treated seedlings.

In gel activity analysis of SOD unveiled a total of seven isoforms in response to As and/or SA. Exposure to $\mathrm{T} 2(10 \mu \mathrm{M}$ As) and $\mathrm{T} 4(100 \mu \mathrm{M} \mathrm{As})$ led decline in the intensities of isozymes-I to IV on $5^{\text {th }}$ day of investigation, compared to $2^{\text {nd }}$ day (Figure 2). Additionally, intensities of isoforms-I and III were reduced in $\mathrm{T} 2$ and $\mathrm{T} 4$ as compare to $\mathrm{MW}$-treated control on $2^{\text {nd }}$ day of treatment. In contrast, isozyme-I displayed increased activity in response to SA, and was also supported by biochemical data (Figures 1and 2). 


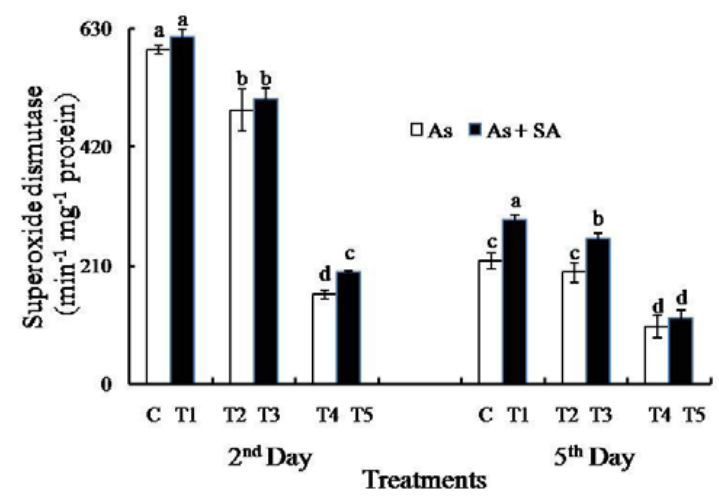

Figure 1. Change in the activity of superoxide dismutase in Glycine max L. radicles exposed to various treatments of arsenic and/ or salicylic acid for two and five days. In this graph, $\mathrm{C}=$ control, T1 $=500 \mu \mathrm{M} \mathrm{SA}, \mathrm{T} 2=10 \mu \mathrm{M} \mathrm{As}$, $\mathrm{T} 3=10 \mu \mathrm{M} \mathrm{As}+500 \mu \mathrm{M} \mathrm{SA}, \mathrm{T} 4=100 \mu \mathrm{M}$ As and T5 $=100 \mu \mathrm{M} \mathrm{As}+500 \mu \mathrm{M} \mathrm{SA}$. Each bar is mean $\pm \mathrm{SD}$ of five distinct observations. Data were statistically analyzed separately for both the harvest days. Different lowercase letters indicate significant differences at $\mathrm{P}<0.05$.

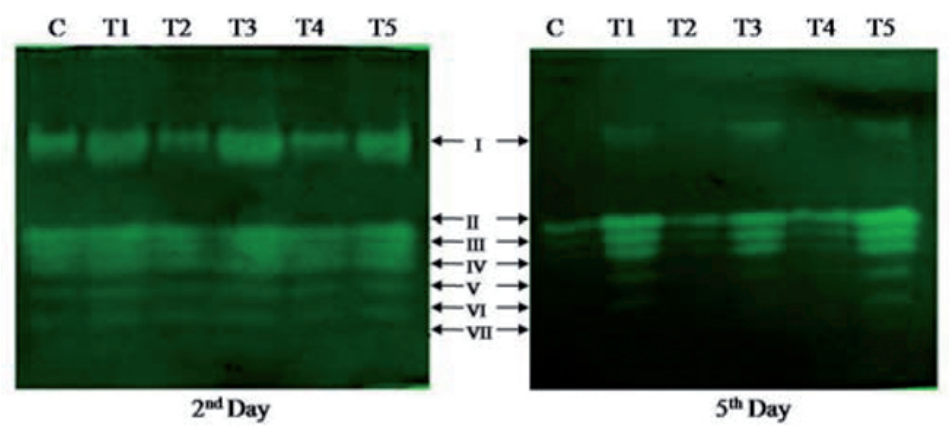

Figure 2. Native-PAGE analyses of superoxide dismutase of Glycine max L. under treatments of arsenic alone or along with salicylic acid, on $2^{\text {nd }}$ and $5^{\text {th }}$ days of incubation. In this figure, $\mathrm{C}=$ control, $\mathrm{T} 1=500 \mu \mathrm{M} \mathrm{SA}, \mathrm{T} 2=10$ $\mu \mathrm{M}$ As, $\mathrm{T} 3=10 \mu \mathrm{M}$ As $+500 \mu \mathrm{M} \mathrm{SA}, \mathrm{T} 4=100 \mu \mathrm{M}$ As and $\mathrm{T} 5=100 \mu \mathrm{M} \mathrm{As}+500 \mu \mathrm{M} \mathrm{SA}$. 


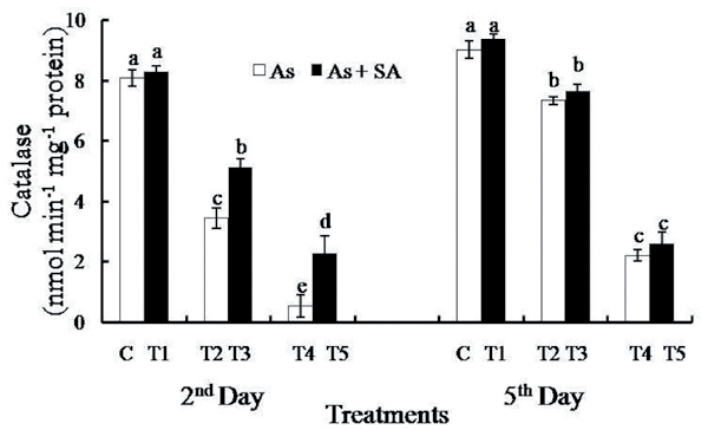

Figure 3. Variation in the catalase activity of Glycine $\max$ L. radicles incubated in various concentrations of arsenic and/ or salicylic acid for two and five days. In this graph, $\mathrm{C}=$ control, T1 $=500 \mu \mathrm{M} \mathrm{SA}, \mathrm{T} 2=10 \mu \mathrm{M}$ As, $\mathrm{T} 3=10 \mu \mathrm{M} \mathrm{As}+500 \mu \mathrm{M} \mathrm{SA}, \mathrm{T} 4=100 \mu \mathrm{M}$ As and T5 $=100 \mu \mathrm{M}$ As $+500 \mu \mathrm{M} \mathrm{SA}$. Data of both the days were analyzed separately. Each bar is mean $\pm \mathrm{SD}$ of five distinct observations. Different alphabets indicate significant differences at $\mathrm{P}<0.05$.
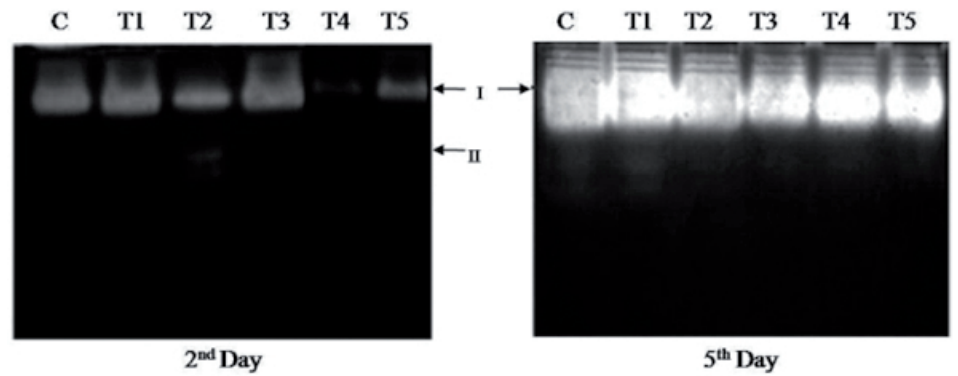

Figure 4. Isozyme pattern of catalase enzyme of Glycine max L. radicles exposed to arsenic and/ or salicylic acid for two and five days. In this figure, $\mathrm{C}=$ control, $\mathrm{T} 1=500 \mu \mathrm{M} \mathrm{SA}, \mathrm{T} 2=10 \mu \mathrm{M} \mathrm{As}, \mathrm{T} 3=10 \mu \mathrm{M} \mathrm{As}+500 \mu \mathrm{M}$ $\mathrm{SA}, \mathrm{T} 4=100 \mu \mathrm{M}$ As and $\mathrm{T} 5=100 \mu \mathrm{M}$ As $+500 \mu \mathrm{M} \mathrm{SA}$.

Analysis of CAT in As-treated Glycine $\max$ L. revealed presence of two isoforms (Figure 4). These are relatively more intense in $\mathrm{T} 2(10 \mu \mathrm{M} \mathrm{As}), \mathrm{T} 3(10$ $\mu \mathrm{M}$ As $+500 \mu \mathrm{M} \mathrm{SA})$ and $\mathrm{T} 5(100 \mu \mathrm{M} \mathrm{As}+500$ $\mu \mathrm{M} \mathrm{SA})$ grown radicles, than the $\mathrm{T} 4(100 \mu \mathrm{M}$ As $)$. Moreover, these are more intense in $5^{\text {th }}$ day samples than the $2^{\text {nd }}$ day, and are well supported by their spectrophotometric data (Figures 3 and 4).

Native-PAGE of POD resolved six isoforms of it (Figure 6). Relative to the control,intensities of isoforms- to $\mathrm{V}$ were increased substantially with increased As, but restored with exogenous SA addition on both the days of analysis. Analysis of APX identified three and six isoforms on $2^{\text {nd }}$ and $5^{\text {th }}$ days respectively (Figure 8). Isoforms-III and VI is common in all the samples of both the days.

Additionally, two new isoforms (II and IV) were found to be induced exclusively in response to SA on $5^{\text {th }}$ day of treatment, but were absent on $2^{\text {nd }}$ day. 


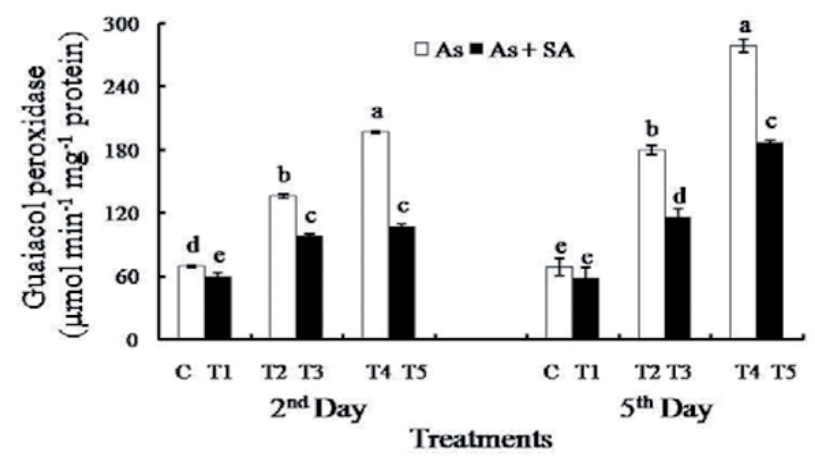

Figure 5. Change in the activity of guaiacol peroxidase in growing radicles of Glycine max L. under different concentrations of arsenic and/ or salicylic acid for two different time lengths. In this graph, $\mathrm{C}=$ control, T1 $=500$ $\mu \mathrm{M} \mathrm{SA}, \mathrm{T} 2=10 \mu \mathrm{M}$ As, T3 $=10 \mu \mathrm{M}$ As $+500 \mu \mathrm{M} \mathrm{SA}, \mathrm{T} 4=100 \mu \mathrm{M}$ As and T5 $=100 \mu \mathrm{M}$ As $+500 \mu \mathrm{M}$ SA. Each bar is mean $\pm \mathrm{SD}$ of five distinct observations. Data of both the days were statistically analyzed separately. Different letters indicate significant differences at $\mathrm{P}<0.05$.

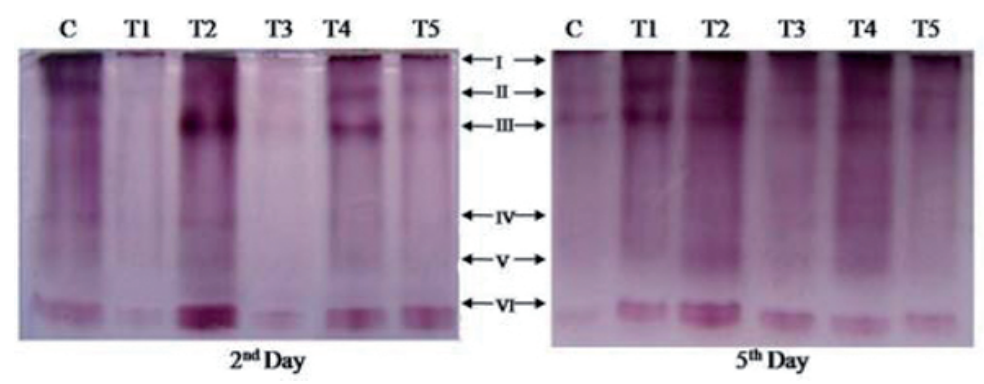

Figure 6. Isozymic analyses of guaiacol peroxidase enzyme of arsenic and/ or salicylic acid treated Glycine max L. radicles of $2^{\text {nd }}$ and $5^{\text {th }}$ days. In this figures, $\mathrm{C}=$ control, $\mathrm{T} 1=500 \mu \mathrm{M} \mathrm{SA}, \mathrm{T} 2=10 \mu \mathrm{M} \mathrm{As}, \mathrm{T} 3=10 \mu \mathrm{M} \mathrm{As}+500$ $\mu \mathrm{M} \mathrm{SA}, \mathrm{T} 4=100 \mu \mathrm{M}$ As and T5 $=100 \mu \mathrm{M}$ As $+500 \mu \mathrm{M} \mathrm{SA}$.

\subsection{Proline}

The level of proline in Glycine max L. significantly $(\mathrm{P}<0.05)$ enhanced in response to As (Table 1). Proline accumulation was found to be higher (858\%) in high As (T4: $100 \mu \mathrm{M})$ subjected seedlings than that of low As (T2: $100 \mu \mathrm{M})$. Data exhibited a close association of it with As concentration $(\mathrm{r}=0.98, \mathrm{P}<0.05)$, and length of exposure $(\mathrm{r}=$ $0.99, \mathrm{P}<0.05)$. Gathered data revealed that exogenous SA (T3 and T5) stimulated accumulation of proline as compared with the corresponding As level (T2 and T4). Maximum amount of proline (2.66 $\mathrm{mg} \mathrm{g}^{-1} \mathrm{FM}$ ) was measured in $\mathrm{T} 5$ $(100 \mu \mathrm{M} \mathrm{As}+500 \mu \mathrm{M} \mathrm{SA})$ subjected radicles (Table 1). 


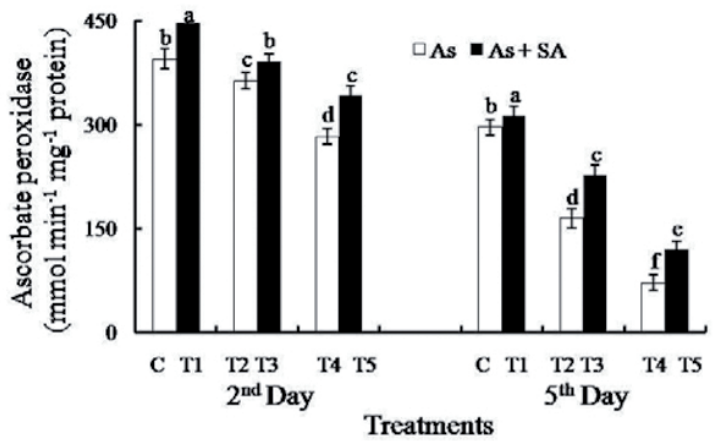

Figure 7. Activity of ascorbate peroxidase in Glycine max L. radicles exposed to various treatments of arsenic and/ or salicylic acid for two and five days. In this graph, $\mathrm{C}=$ control, $\mathrm{T} 1=500 \mu \mathrm{M} \mathrm{SA}, \mathrm{T} 2=10 \mu \mathrm{M} \mathrm{As}, \mathrm{T} 3=10$ $\mu \mathrm{M} \mathrm{As}+500 \mu \mathrm{M} \mathrm{SA}, \mathrm{T} 4=100 \mu \mathrm{M}$ As and T5 $=100 \mu \mathrm{M}$ As $+500 \mu \mathrm{M}$ SA. Data of both the days were separately analyzed. Each bar is mean $\pm \mathrm{SD}$ of five distinct observations. Different small alphabets indicate significant differences at $\mathrm{P}<0.05$.

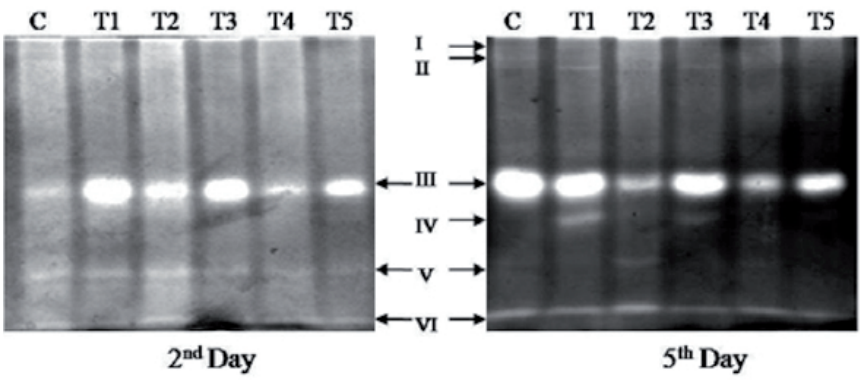

Figure 8. Native-PAGE analyses of ascorbate peroxidase of Glycine max L. seedlings exposed to various concentrations of arsenic and/ or salicylic acid for two and five days. In this figure, $\mathrm{C}=$ control, $\mathrm{T} 1=500 \mu \mathrm{M} \mathrm{SA}, \mathrm{T} 2=$ $10 \mu \mathrm{M} \mathrm{As}, \mathrm{T} 3=10 \mu \mathrm{M}$ As $+500 \mu \mathrm{M} \mathrm{SA}, \mathrm{T} 4=100 \mu \mathrm{M}$ As and $\mathrm{T} 5=100 \mu \mathrm{M}$ As $+500 \mu \mathrm{M}$ SA.

\section{Discussion}

Arsenic-toxicity constitutes one of the major abiotic threats that not only disturb crop production instead human health also. Recent reports revealed that exogenous application of certain chemicals may result in the alleviation of various abiotic stresses that could be important from both theoretical and applied point of views (Namdjoyan and Kermanian,
2013; Singh et al., 2015a). Among such chemicals, $\mathrm{SA}$ is recently receiving increasing attention due to its involvement in the plant growth regulation and abiotic stress tolerance mechanism (Dong et al., 2015). Inhibitory impact of As on Glycine max L. seed was scrutinized by recording the changes in germination rate, length and DM of the radicles under pre-fixed doses of As $(10$ and $100 \mu \mathrm{M})$ and increase in exposure time ( 2 and 5 days). Study of 
time-dependent alterations is a functional approach to assess time course changes in DM accumulation. In general, growth and DM accumulation of Glycine max L. were negatively ( $r=-0.98, \mathrm{P}<0.05)$ influenced by As (Table 1). This growth inhibition could partly be due to the reduction in cell division rate (Chandrakar et al., 2016). Our observations are substantiated with those of Chun-xi et al. (2007) and Singh et al. (2015b). Arsenic is well known to affect adversely the plants growth and development upon its accumulation. A study conducted on Solanum melongena L. also demonstrated such a concentration dependent influx of As (Singh et al., 2015b). In the present study, exogenous SA significantly counteracted the reductions in growth caused due to As-toxicity by lowering its accumulation in Glycine max L. Moreover, SA was shown to involve actively in the regulation of overall growth and development of the plants (Kazemi et al., 2010).

Contamination of As in plants has closely been linked to oxidative damage via over production of ROS. Of note, our results indicated that amount of ROS increased significantly (524-2880\%) with As addition (Table 2), hence correlated with length of exposure $(\mathrm{r}=0.99, \mathrm{P}<0.05)$ and As concentration $(\mathrm{r}=0.86, \mathrm{P}$ $<0.05$ ). Like ours, As-induced rise in the ROS was also documented in the Phaseolus aureus L. and Nasturtium officinale (Kaur et al., 2012; Namdjoyan and Kermanian, 2013). While exogenous SA counteracted the As-induced increase in ROS levels (Table 2). Our findings are in line with that of Odjegba (2012) and Singh et al. (2015a) in Arabidopsis thaliana and Oryza sativa L. SA mediated lowering in ROS indicates a protective role against As-stress.

Addition of As manifested remarkable rise (744\%, P < 0.05 ) in the LOX activity as compared to control (Table 2). Similar change was also noted in As-stressed Nasturtium officinale (Namdjoyan and Kermanian, 2013). It has been proposed that stress-induced increment in LOX is a reflection of higher lipolytic activity in cellular membranes, and increased oxidation of membrane-bound fatty acids (Kazemi et al., 2010). However, in this study exogenous SA declined $(\sim 50 \%)$ the LOX activity in Glycine max L., and was well supported by the report of Kazemi et al. (2010). Alleviation of oxidative damage by scavenging ROS via antioxidant enzymes is an important strategy of plants to protect them against stresses. In this study, activities of SOD, CAT, POD and APX were altered in response to As and/ or SA (Figures 1-8). Similar change in these enzymes has also been observed by Chun-xi et al. (2007) and Kaur et al. (2012). However, exogenous SA restored the activities of tested enzymes thereby reduced ROS and oxidative damage in Glycine max L. Data approves that the key role of $\mathrm{SA}$ is to serve as a signaling molecule and thereby enhancing the defensive system. Similar results have also been observed by Singh et al. (2015a).

Isozyme charts are molecular level types after gene expression. The intensity of isoform can reflect relative activity of any enzyme. Native-PAGE revealed seven and two isoforms of SOD and CAT respectively in Glycine $\max$ L. subjected to As and/or SA (Figures 2 and 4). Similar patterns of these were also observed by Chun-xi et al. (2007). POD exists in a number of isoforms and has diverse functions in plants metabolism depending on their substrates. $\mathrm{H}_{2} \mathrm{O}_{2}$ has been reported to serve as an essential substrate of POD (Chun-xi et al., 2007). Native-PAGE of POD resolved six bands with different intensities in response to As and SA (Figure 6). Compared to control, intensities of isozymes-I to V were increased in response to As, but restored with SA, approving its involvement in restoring POD activity in As-stressed Glycine max L. Our results are in coherence with Chun-xi et al. (2007). Native-PAGE of APX unveiled three and six isoforms on $2^{\text {nd }}$ and $5^{\text {th }}$ days respectively (Figure 8 ). Moreover, exogenous SA induced two new isoforms (II and IV) 
on $5^{\text {th }}$ day of treatment, but were absent on $2^{\text {nd }}$ day. Mostofa and Fujita (2013) showed that activity of APX was enhanced after addition of SA into Oryza sativa L. Results suggests that exogenous SA regulates antioxidative enzymes, thereby lowers ROS and prevent Glycine max L. against As-stress.

Proline was shown to be accumulated in plants under abiotic stresses (Agami, 2014), and was also found true in this study (Table 1). These results are in agreement with that of Namdjoyan and Kermanian (2013) and Singh et al. (2015b). Its accumulation could possibly be the resultant of As-accrued water imbalance inside the cells. In fact, proline is not only an important molecule in redox signaling, but also serves as a potential ROS scavenger (Agami, 2014).

\section{Conclusions}

Accumulated data clearly demonstrate that interactive effects of As and SA considerably reduced As-toxicity in Glycine max L. (variety JS335). Arsenic inhibited radicle emergence and then elongation in germinating Glycine max L. seeds by inducing ROS-mediated oxidative damage and altering the activities of antioxidant enzymes. Exogenous SA could enhance tolerance of the Glycine max L. to the As-stress through up-regulating the activities of SOD, CAT and APX, and accumulation of proline. Therefore, it can be concluded that the supplementation of SA proved to be beneficial for the plants in combating As-stress. However, further investigation is needed, particularly at gene expression level, to gain deeper understanding in regard to the interaction of As and SA in plants.

\section{Acknowledgements}

The authors thank Prof. Aditi Poddar, School of Life Sciences, Pt. R. S. University, Raipur, for correcting the language/linguistics of the manuscript. Special acknowledgements are due to the editors and reviewers involved all through. The authors would like to thank the Department of Science \& Technology, New Delhi, for awarding INSPIRE fellowship [No. DST/ INSPIRE Fellowship/2013/791, dated 23.01.2013] to Vibhuti Chandrakar. Authors are also grateful to Department of Science \& Technology, New Delhi, for financial support through DST-FIST scheme (Sanction No. 2384/IFD/2014-15, dated 31.07.2014) sanctioned to the School of Studies in Biotechnology.

\section{References}

Agami, R.A. 2014. Applications of ascorbic acid or proline increase resistance to salt stress in barley seedlings. Biologia Plantarum. 58, 341-347.

Armendariz, A.L., Talano, M.A., Travaglia, C., Reinoso, H., Oller, A.L.W., Agostini, E. 2016. Arsenic toxicity in soybean seedlings and their attenuation mechanisms. Plant Physiology and Biochemistry. 98, 119-127.

Bates, L.S., Walrow, R.P., Teare, I.D. 1973. Rapid determination of free proline for water stress studies. Plant and Soil. 39, 205-208.

Bradford, M.M. 1976. A rapid and sensitive method for the quantitation of microgram quantities of protein utilizing the principle of protein-dye binding. Analytical Biochemistry. 72, 248-257.

Chance, M., Maehly, A.C. 1955. Assay of catalases and peroxidases. Methods in Enzymology. 2, 764-817.

Chandra, J., Keshavkant, S. 2016. Physiological and biochemical changes during seed development and maturation in Madhuca latifolia Roxb. Bangladesh Journal of Botany. 45, 335-343.

Chandrakar, V., Naithani, S.C., Keshavkant, S. 2016. Arsenic-induced metabolic disturbances and their mitigation mechanisms in crop plants: A review. Biologia. 71, 367-377. 
Chun-xi, L.I., Feng, S.L., Shao, Y., Jiang, L., Lu, X.Y., Hou, X.L. 2007. Effects of arsenic on seed germination and physiological activities of wheat seedling. Journal of Environmental Sciences. 19, 725-732.

Dong, Y.J., Jinc, S.S., Liu, S., Xu, L.L., Kong, J. 2014. Effects of exogenous nitric oxide on growth of cotton seedlings under $\mathrm{NaCl}$ stress. Journal of Soil Science and Plant Nutrition. 14, 1-13.

Dong, Y.J., Wang, Z.L., Zhang, J.W., Liu, S., He, Z.L., He, M.R. 2015. Interaction effects of nitric oxide and salicylic acid in alleviating salt stress of Gossypium hirsutum L. Journal of Soil Science and Plant Nutrition. 15, 561-573.

Kaur, S., Singh, H.P., Batish, D.R., Negi, A., Mahajan, P., Rana, S., Kohli, R.K. 2012. As inhibits radicle emergence and elongation in Phaseolus aureus by altering starch-metabolizing enzymes vis-à-vis disruption of oxidative metabolism. Biological Trace Element Research. 146, 360-368.

Kazemi, N., Khavari-Nejad, R.A., Fahimi, H., Saadatmand, S., Nejad-Sattari, T. 2010. Effects of exogenous salicylic acid and nitric oxide on lipid peroxidation and antioxidant enzyme activities in leaves of Brassica napus L. under nickel stress. Scientia Horticulturae. 126, 402-407.

Keshavkant, S., Naithani, S.C. 2001. Chilling-induced oxidative stress in young sal seedlings. Acta Physiologiae Plantarum. 23, 457-466.

Lozano-Rodríguez, E., Liguera, M., Lucena, J.J., Carpena, R.O. 1995. Evaluation of two different acid digestion methods in closed systems for trace element determination in plants. Quimica Analitica. 14, 27-30.

Marklund, S., Marklund, G. 1974. Involvement of the superoxide anion radical in the autoxidation of pyrogallol and a convenient assay for superoxide dismutase. European Journal of Biochemistry. 47, 469-474.
Mittler, R., Zilinskas, B.A. 1993. Detection of ascorbate peroxidase activity in native gels by inhibition of the ascorbate-dependent reduction of nitroblue tetrazolium. Analytical Biochemistry. 212, 540-546.

Mostofa, M.G., Fujita, M. 2013. Salicylic acid alleviates copper toxicity in rice (Oryza sativa L.) seedlings by up-regulating antioxidative and glyoxalase systems. Ecotoxicology. 22, 959-973.

Nakano, Y., Asada, K. 1981. Hydrogen peroxide is scavenged by spinach chloroplasts. Plant Cell Physiology. 22, 867-880.

Namdjoyana, S., Kermanian, H. 2013. Exogenous nitric oxide (as sodium nitroprusside) ameliorates arsenic-induced oxidative stress in watercress (Nasturtium officinale R. Br.) plants. Scientia Horticulturae. 161, 350-356.

Odjegba, V.J. 2012. Exogenous salicylic acid alleviates arsenic toxicity in Arabidopsis thaliana. Indian Journal of Innovations and Developments. 7, 515-522.

Olaiya, C.O. 2010. Enzyme activity in bioregulatortreated Solanum lycopersicon genotypes. African Journal of Biotechnology. 9, 3264-3271.

Parkhey, S., Naithani, S.C., Keshavkant, S. 2014a. Protein metabolism during natural ageing in desiccating recalcitrant seeds of Shorea robusta. Acta Physiologiae Plantarum. 36, 1649-1659.

Parkhey, S., Tandan, M., Keshavkant, S. 2014b. Salicylic acid and acquisition of desiccation tolerance in Pisum sativum seeds. Biotechnology. 13, 217-225.

Raza, M.A.S., Saleem, M.F., Shah, G.M., Khan, I.H., Raza, A. 2014. Exogenous application of glycinebetaine and potassium for improving water relations and grain yield of wheat under drought. Journal of Soil Science and Plant Nutrition. 14, 348-364. 
Schopfer, P., Plachy, C., Frahry, G. 2001. Release of reactive oxygen intermediates and peroxidase in germinating radish seeds controlled by light, gibberellin and abscisic acid. Plant Physiology. 125, 1591-1602.

Singh, A.P., Dixit, G., Mishra, S., Dwivedi, S., Tiwari, M., Mallick, S., Pandey, V., Trivedi, P.K., Chakrabarty, D., Tripathi, R.D. 2015a. Salicylic acid modulates arsenic toxicity by reducing its root to shoot translocation in rice (Oryza sativa L.). Frontiers in Plant Science. 6, 1-12.

Singh, M., Singh, V.P., Dubey, G., Prasad, S.M. 2015b. Exogenous proline application ameliorates toxic effects of arsenate in Solanum melongena L. seedlings. Ecotoxicology and Environment Safety. 117, 164-173.
Srivastava, O.P., Huystee, R.B. 1977. An inter-relationship among peroxidise, IAA oxidase and polyphenol oxidase from peanut cells. Canadian Journal of Botany. 55, 2630-2635.

Velikova, V., Yordanov, I., Edreva, A. 2000. Oxidative stress and some antioxidant systems in acid rain treated bean plants: protective role of exogenous polyamines. Plant Science. 151, 59-66.

Woodbury, W., Spencer, A.K., Stahmann, M.A. 1971. An improved procedure using ferricyanide for detecting catalase isozymes, Analytical Biochemistry. 44, 301-305. 